\title{
Innovation in the Norwegian Rural Tourism Industry: Results from a Norwegian Survey
}

\author{
Martin Rønningen*
}

Lillehammer University College and Centre for Rural Research, N-2624 Lillehammer, Norway

\begin{abstract}
This paper focuses on innovation in the rural tourism industry. The data is a survey including 133 Norwegian rural tourism enterprises. The operational definition of innovation in this study is quite similar to the one used in the European innovation studies, the Community Innovation Survey, conducted by Eurostat. The seven hypotheses in this study are deduced from the review of the literature. The survey indicates rather high rates of innovations among rural tourism enterprises even if the rates are somewhat lower than the average of other tourism enterprises in Norway. The rural tourism enterprises' innovative capacity is closely associated with the enterprises' involvement in cooperation, use of market-information systems, and actions taken to increase the employees' competence. Additionally, the enterprises with an exporting orientation generate more product innovations than other enterprises. Enterprises that acquire public grants have also on average implemented more product and market innovations compared with the rest of the enterprises. The findings give grounds for some practical recommendations. Finally, more research is needed due to the fact that research on innovation has rarely focused on small-scale, rural tourism enterprises.
\end{abstract}

Keywords: Rural tourism, innovation, types of innovation, antecedents for innovation.

\section{INTRODUCTION}

Over the past decades rural areas in many countries have faced the pressures of economic transition. Traditionally, strong primary industries such as fishing, agriculture, and forestry have declined dramatically, and many places have viewed tourism and related industries as replacements for traditional rural livelihoods [1-4]. In Norway, tourism is also considered as an instrument for increasing both employment in rural areas and female employment in general [5].

There is some documentation that offer optimistic assessments of the tourism industry's potential of growth in rural areas $[1,3]$. Hjalager claims, however, that innovative capacity is a prerequisite for growth in the tourism industry [6]. This consideration is in accordance with the renewed interest in the relationship between innovation and economic growth $[7,8]$. Hence, it is worthwhile to draw attention to innovation in the tourism industry in general and in the rural tourism industry in particular.

A number of researchers have claimed that the tourism industry's innovative ability is quite low and needs improvement $[6,9-11]$. Yet, apart from the sole exception of one Danish study, no studies have explored extensively the innovation activities in the tourism industry, including rural tourism [12]. Furthermore, the regular studies on innovation that are conducted by the Statistical Office of the European Communities (Eurostat), Community Innovation Study, have not even included the tourism industry [13].

In Norway this deficiency has been moderated because Lillehammer University College has recently carried out a

*Address correspondence to this author at the Lillehammer University College and Centre for rural research, N-2624 Lillehammer, Norway; Tel : +4761288318; Fax: +4761288170; E-mail: Martin.Ronningen@hil.no national survey dealing with innovation in tourism enterprises. The survey also includes tourism enterprises in rural settings. This paper focuses solely on the subject of innovation in the rural tourism industry, and the data from the aforementioned survey is the basis of the analyses presented here.

The aim of the paper is thus to give a picture of the innovativeness in the Norwegian rural tourism industry that includes rates of innovation and, in particular, analyses of the variance of innovations in rural tourism firms. The analyses provided here may be considered especially noteworthy because no previous studies of innovative activities in rural tourism have been grounded on a national survey. The theoretical ambition of this paper is to develop and test empirically a model of driving forces and antecedents of innovative behaviour in rural tourism firms.

The following section deals with the term of 'rural tourism'. The third section reviews the literature on innovation in the tourism industry, and the fourth deduces some hypotheses about innovation in the rural tourism industry. The fifth section addresses the research method. The subsequent sections present and discuss the findings.

\section{Rural Tourism}

As a concept, rural tourism is difficult to define, and it is hardly possible to find a commonly accepted definition, or an agreed set of characteristics, of rural tourism [14]. According to Lane, rural tourism should ideally be located in rural areas and should be functionally rural and rural in scale. Lane has suggested, furthermore, that rural tourism should comprise small-scale enterprises owned by local family units, that the services should relate to local history, including traditional ways of living and agrarian economies, and that the activities should take place in relatively natural 
settings [15]. In reality, many forms of rural tourism, or tourism in rural areas, do not conform to these lofty principles [14]. In reality, rural tourism activities and attractions differ by their location, style of management, and degree of integration with the natural and cultural surroundings [1]. One may argue, then, in favour of a more general definition of rural tourism: tourism that takes place in the countryside [16]. This simple definition, however, contains a number of ambiguities.

First, the definition of tourism itself can vary, especially within the context of the countryside, because boundaries between tourism activities (strictly speaking), leisure, and sport can be blurred. Secondly, it is difficult to define what is meant by the 'countryside' or 'rural areas'. Many countries have differing criteria on which to judge which areas are rural or non-rural. The term 'rural' can also be both a geographical definition and a description of cultural aspects of communities in the countryside. And finally, the term of 'rural tourism' is quite often used synonymously with ecotourism, green tourism, nature tourism, and agritourism [14]. Consequently, previous research on rural tourism have included many approaches to the analysis of rural tourism as both an economic sector and a socio-cultural practice [17].

As definitions of rural tourism are ambiguous, an appropriate definition for the purpose of this paper is necessary. The subject under consideration is innovative activities in enterprises. The definition of tourism should then focus on the supply side, that is, the tourism industry. According to Leiper, the tourist industry comprises, “... firms, organizations and facilities which are intended to serve the needs and wants of tourists" [18]. In a rather pragmatic way, we may, then, classify the rural tourism industry as the tourism industry located in rural areas, and it consists of enterprises which are rural in scale, that is, smallscale enterprises [15]. The section of methodology presents a more specific and operational definition.

\section{What is Innovation?}

Schumpeter is the classical theorist of innovation research. He has outlined a theory of entrepreneurship which argues that entrepreneurs create innovations in the face of competition and falling profits. According to Schumpeter, the spurts of these kinds of entrepreneurial activities generate economic growth. Schumpeter distinguished between five forms of innovation [19].

Later, inspired by Schumpeter's definitions, other scholars have introduced a number of typologies [7]. The Community Innovation Survey (CIS), executed by national statistical offices throughout the European Union, also uses definitions quite similar to Schumpeter's. The CIS differentiates between product innovation, process innovation, organisational innovation, and market innovation [13]. Every major type of innovation is measured by several questions.

Some researchers have questioned whether the theory of innovation developed in relation to the manufacturing sector is applicable to service sectors $[20,21]$. The main objection is that the service industry has an intangible and interactive nature; because service output does not have a physical existence, and service innovation can be almost invisible.
Also, services are often adapted to the customers' changing requirements, and thus it can be difficult to distinguish between the adaptation of services to customers' preferences, on the one hand, and service innovation, on the other [2225]. A related complication is that service innovation typically occurs as a continuous change or as minor changes of service products or procedures rather than as discrete jumps, such as those that accompany innovation in the context of manufacturing [26]. Besides, the knowledge base of service innovation generally comes from skills, organisational practice, and practical experiences, rather than from research results and technological breakthroughs [21, 24, 27].

Notwithstanding the debate on the definition and understanding of innovation, the proposed typologies for innovation in the service sector do not differ substantially from, for instance, the CIS typology. Sundbo and Gallouj have proposed a typology of innovation adjusted to the service sector that includes the same major innovation types used by the CIS [26]. In other words, Sundbo and Gallouj's typology includes roughly the same categories as used by CIS. However, they noted that innovation in services, including tourism, can be minor and exhibit more gradual changes of service products. The Norwegian survey on innovation in the tourism industry uses the definitions of innovations from the CIS.

\section{Previous Research on Innovation in the Tourism Industry}

We have noted already that the map of innovative activities in the tourism industry is underdeveloped, in Norway and in many other countries. Although there are a number of studies that have been published, they either are rather fragmentary or centre on limited case studies (see below).

The main exception is a Danish survey of innovation in the service industries that includes an extensive study of innovation in tourism [12]. The survey demonstrates that the tourism industry has a rather low rate of innovation compared with other service industries. The researchers explain this tendency by several factors. One is the size of enterprises. The tourism industry includes many micro and small enterprises, and studies have documented that innovative capacity is positively correlated with business size [28-30]. Another factor that may relate to the size of companies is a lack of adequate managerial systems to support innovative activities. Furthermore, many tourism enterprises are not involved in cooperative or collaborative structures which can strengthen innovative capacity.

Hjalager has commented on the inadequate innovative activity in tourism [6]. She claims there is little mutual trust between tourism enterprises. Ownership, at least in Denmark, also changes quickly, which impedes the development of trust-based collaborative relations. Consequently, small enterprises do not participate in appropriate collaborative constellations, a pattern which in turn restricts the transfer of knowledge and experience and hampers innovative capacity. Hjalager has also emphasised that employees usually have a low level of competence owing to high turnover rates and to a lack of industry-relevant training. 
Thus, many tourism enterprises cannot meet the knowledge requirements for innovation.

Despite the obstacles to the development of innovative processes in the tourism sector, Hjalager has suggested a solution. She proposes that the transfer of knowledge to the tourism industry can still take place in different ways through other organisations that are involved in, or support, the tourism industry. The knowledge transfer channels suggested by Hjalager comprise the trading system, the infrastructural system, the regulatory system, and the technological system. These collaborative structures, Hjalager emphasises, can act as a means of improving the individual enterprises' access to knowledge, competence, and consultancy.

By noting that the innovative potential on micro level, that is, in the single, small tourism enterprise, is very limited, Mattson, Sundbo, and Fussing-Jensen have almost the same starting point as Hjalager [10]. According to Mattson, Sundbo, and Fussing-Jensen, the innovative potential can be better at the meso level. While Hjalager has primarily focused on supportive systems and channels of knowledge transfer, such as remedial action, Mattson, Sundbo, and Fussing-Jensen have looked for innovative potential in another system. They propose an attractor-based system of innovation whereby the attractor and the scene-maker are the distinct originators of innovation. The scene-maker, or the innovator, starts the process by becoming aware of an attractor, which is something that creates attention and draws visitors. The scene-maker creates a scene by providing a context for the attractor and by constructing a concept that characterises the attraction on the basis of the attractor. The scene requires constant maintenance and improvements to keep visitors' attention over time. These are done by another entrepreneur in the system, the scene-taker. Local firms like hotels, restaurants, transporters, shops, etc. have to exploit the possibilities of the location and the scene, and can benefit from the scene and the scene-taker's efforts by participating in a collaborative network that emerges on the scene. In other words, as Mattson, Sundbo, and Fussing-Jensen have suggested, there is one possible solution that involves a form of cooperation within the frame of a small-scale system of innovation, whereby the scene-maker is the innovator and the scene-taker the entrepreneur, and both constitute the driving forces in the system.

Pechlaner, Fischer, and Hammann have also pointed to the structure of the tourism industry, which is characterised by many small enterprises, as an obstacle to innovation [31]. In order to increase innovative ability, they have suggested a strategy of inter-organisational networks and cooperation. They also claim that decentred leaders, i.e., managers of tourism organisations, should coordinate and manage the cooperation and networks in order to ensure the flow of knowledge and to reduce the transaction costs of the enterprises involved. Pechlaner, Fischer, and Hammann's empirical analysis indicates that collaboration on the transfer of knowledge and experience increases the enterprises' overall innovative capacity.

Sørensen has similarly been concerned about collaboration and interaction between actors [32]. He has studied the effect of networks on innovation. His study, in particular, focuses on how different configurations of networks inf- luence the flow of information. Sørensen has concluded that networks provide accommodation enterprises with the information that increases their innovative ability. The differences in networks regarding density and strength did not, however, explain the innovative behaviour of the enterprises.

Orfila-Sintes, Crespi-Cladera, and Martinez-Ros have found differences in innovative capacity between chain hotels and independent hotels on the Balearic Islands [33]. The chain and franchise hotels exhibited better innovative capacity than the independent hotels. Thus, the collaborative structure given by chain membership, in one way or another, seemed to increase the enterprises' innovative ability. Additionally, standard and size of the hotels also influenced the presence of innovative activities.

While many of the studies above emphasise relations between tourism enterprises or between enterprises and other actors, Ottenbacher, Shaw, and Lockwood have partially taken a supplementary focus [34]. They have drawn attention to the management and internal processes of the individual firms in addition to the external relations and cooperation. Ottenbacher et al. have studied innovation with two different types of hotels in Germany, independently operated hotels and chain-affiliated hotels. The researchers have tried to identify factors that can explain innovation successes. They found that market orientation, adequate management, and internal processes, among other things, improved the enterprises' economic outcome. The researchers also underline that independent hotels must give priority to acquiring and improving competence because they do not receive information, competence, advice or training from a chain's headquarter. Independent hotels also have to work harder with marketing than chain-affiliated enterprises because the independent ones cannot benefit from a chain's infrastructure of marketing. In short, Ottenbacher, Shaw, and Lockwood have emphasised the advantages of collaborative structures that chain affiliation offers. Furthermore, they have accentuated the importance of internal processes in the enterprises: market orientation, management, and efforts to improve competence.

In Norway, Bolkesjø, Haukeland, and Vareide have explored the innovative activity and the need of innovation at seven rural destinations [35]. They have found that the innovative activity varied significantly between the destinations. The destinations with the best innovative performance had strong local tourism organisations. This fact supports Pechlaner, Fischer, and Hammann's findings on the critical role of strong local or regional leadership [31]. Additionally, the enterprises expressed the need for increased competence, more cooperation, and more marketing.

There is also a pilot study on the potentials for innovation in the Norwegian rural tourism industry that has focused on cooperation as a way of increasing innovative capacity. The study indicates that different kinds of cooperation and collaborative structures might improve the innovative activities [36].

Many of the aforementioned publications call attention to cooperation as a remedial action for increasing innovative ability. An analysis of innovation across seven European countries has also indicated that cooperation tends to 
increase innovation [28]. The national study of innovation in the Norwegian industries has shown the same tendency [30]. Tehter's analysis of innovation in the service industry in 15 European states did not focus on the connection between cooperation and innovation directly, but a significant share of the service enterprises stated that cooperative practices are important in strengthening innovation [21]. His analysis also showed that cooperation with customers and suppliers is the service enterprises' most widely used means of accessing advanced technologies.

The focus on cooperation is in accordance with the systemic perspective on innovation. Theories and research on innovation often emphasise the system of innovation and the processes within the system that bring about innovation [37-40]. The systemic perspective regards knowledge and competence as the core resources and learning as the fundamental process in the system that generates innovations [41]. The perspective emphasises interaction between different actors (i.e., autonomous enterprises, research-and-development institutions, and governmental bodies), and their exchange of knowledge, experiences, and advice. As this perspective stresses knowledge and learning, it is also reasonable to assume that those enterprises that give priority to obtaining relevant information from external sources, say, market information, will increase their knowledge and obtain information either individually or jointly.

Employees within an enterprise may also be a source of knowledge and information that is relevant for the innovation capacity. Salte's analysis of innovation in the Norwegian industries indicates that the enterprises perceive information from their employees as more important than information from external sources [30]. The involvement of employees in innovative processes can, then, lead to increased information, experiences, and knowledge, either codified or tacit, through interactional processes [42]. If employees' competence is important, we can also deduce that the employers' efforts to increase employees' qualifications and competences will improve the enterprises' innovative capacity.

Besides the enterprises' individual or joint efforts to strengthen innovative capacity, governmental support may also improve the enterprises' innovative ability. The triplehelix model and related theories about systems of innovation assign a role to governmental bodies in processes of innovation $[43,44]$. The government's influence may be an effect of institutional frameworks that affect research and the development of knowledge and competence. In addition, the government can affect enterprises' innovative activities by means of taxes, legislation or grants. Lien's and Teigen's analysis, for example, indicates that governmental grants advance Norwegian tourism enterprises' innovative ability [45].

Finally, it should be mentioned that Tether's analysis demonstrates that enterprises with an exporting orientation (measured by exports as proportions of sales) have more product innovations than other enterprises [21].

Few studies have focused specifically on innovation in the rural tourism industry. Many tourism enterprises are, however, located in rural regions, and are for that reason implicitly included in many of the studies referred to above. Furthermore, many tourism enterprises are small enterprises or even micro enterprises. The reviewed literature should, then, be of relevance for our analysis of the rural tourism industry.

In conclusion, previous research indicates the following: tourism enterprises have rather low innovative capacity; small enterprises have less innovative capacity than larger ones; cooperation in one way or another strengthens innovative ability; knowledge and competence is decisive for innovative capacity; public grants may improve the enterprises' innovative ability; and an exporting orientation

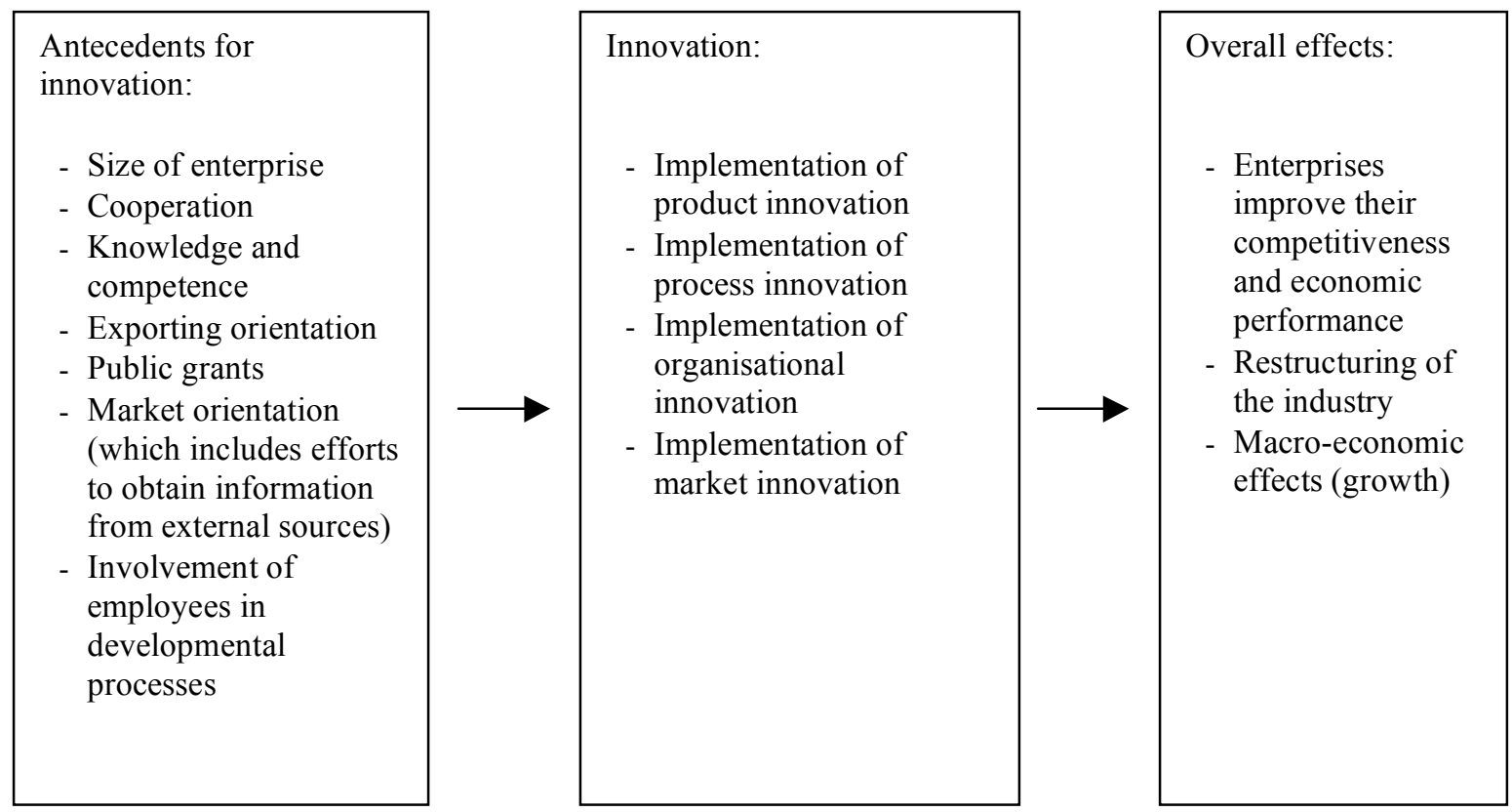

Fig. (1). A conceptual model of antecedents for innovation, and overall effects. 
pushes for product innovation. Furthermore, previous research implies that the enterprises' market orientation and involvement of employees may increase innovativeness.

If we combine the review about factors that facilitate innovation with the theoretical reasoning about innovation and the output of innovation, we may illustrate the result with the model below.

The subject of this paper is innovation in the rural tourism enterprises, confined to innovation rates and the factors that may explain the variance in innovative activities. Hence, the model exceeds the limits of the research question of this paper. One of the main components of the model, labelled 'overall effects', is included simply to furnish a more complete picture of processes of innovation and their final effects. One of these effects, the enterprises' improved competitiveness and improved economic performance, is a rather obvious outcome if the enterprises innovate successfully. A potential large-scale effect of innovation would be the restructuring of an industry. According to Schumpeter, this substantial effect may occur as a result of the implementation of radical innovations [19]. One example is Thomas Cook's introduction of the travel agency, which embodied a new concept of travel and entertainment for a new segment of customers, together with an efficient organisation that made it possible to provide the services at a favourable price. Furthermore, innovations may spur more or less macroeconomic growth depending on how radical the implemented innovation may be or the degree of diffusion of the innovation.

As already mentioned, the antecedents illustrated in the model are deduced from the review of literature. The next section will elaborate on the associations between the antecedents and innovation.

\section{Hypotheses}

Based on the review above, we hypothesise the following:

1. The innovative activity in rural tourism enterprises is low. In general, the innovative capacity in the tourism industry seems to be low. Thus, we can expect that rural tourism enterprises that are small and probably unfavourably localised regarding their industrial and economic surroundings have very limited innovative activity. We anticipate at the very least that the innovativeness in rural tourism enterprises is considerably lower than the average for other Norwegian industries.

2. Rural tourism enterprises participating in appropriate cooperation are more innovative than those enterprises that are not involved in cooperation. In this context, appropriate cooperation is primarily a matter of cooperation or professional relations established to improve the participants' innovative capacity.

3. Enterprises that give priority to obtaining relevant information from external sources, for example, market information, are more innovative than those enterprises that do not perform such actions.

4. Enterprises that take action to increase employees' competence are more innovative than other enterprises
5. Enterprises that involve employees in the developmental processes are more innovative than other enterprises.

6. Enterprises that qualify for public grants are more innovative than other enterprises.

7. Enterprises with an exporting orientation (measured by exports as proportions of sales) offer more product innovations than other enterprises.

The review of the literature also indicates that innovative ability increases with the size of enterprises. However, all the rural tourism enterprises in the sample are small ones. The variable Size of enterprise is not, then, as relevant as it may be in an analysis of the total tourism industry where the amount of variance is larger. All the same, we use the size of enterprise as a control variable in the analysis.

\section{METHODOLOGY}

The data-set examined in this paper is a section of a survey including 452 Norwegian tourism enterprises. A simple random sampling from a national database that includes all Norwegian enterprises, Lindorf's database (which is founded on Statistics Norway's Business Register and units in the Central Coordinating Register of Legal Units), produced a selection of 1300 enterprises. The population of tourism enterprises was defined by choosing all enterprises with specific codes in Standard Industrial Classification (SIC2002) [46]. Enterprises with the following codes were included: 55.1 Hotels, 55.2 Camping sites and other provision of short-stay accommodation, 55.3 Restaurants, 55.4 Bars, 55.5 Canteens and catering, 63.301 Travel agencies, 63.302 Tourist offices, 63.303 Tour operators, 63.304 Tour guides and leaders, 63.305 Adventure, event, and activities operators, 63.309 Touristrelated activities, 92.330 Fair and amusement-park activities, 92.521 Museums activities, 92.721 Activities and adventure companies, and 92.729 Other recreational services.

The interviews were done by telephone in January and February 2008. NORSTAT, a firm that conducts data collection in many European countries, carried out the interviews. There were 201 enterprises that refused to answer the questionnaire. In addition, the interviewers were not able to contact 599 enterprises because they did not answer the phone calls. Accordingly, 34.8 per cent of the total sample answered the questionnaire. The response rate of 0.348 was calculated according to the Response Rate 1 formula from the American Association for Public Opinion Research.

We may interpret a selection of the sample as rural tourism enterprises. Above, we have defined rural tourism industry as small-scale tourism enterprises located in rural areas. In other words, small-scale enterprises and rural areas are the criteria by which to define the rural tourism industry. We have used a rather pragmatic operational definition of small-scale enterprises, that is, enterprises with ten employees or less (including full- and part-time employees). This definition is the same as in the definition of micro enterprise proposed by the European Union [47]. Rural areas are characterised by geographical criteria based on Statistics Norway's centrality index [48]. More precisely, the definition of rural areas covers those municipalities on the three 
lowest levels of geographical centrality in Norway. According to this demarcation, rural areas are rather remote settings with low population densities, and they are located relatively far from urban settlements and regional centres.

By using these criteria, the total survey comprising 452 Norwegian tourism enterprises includes 133 rural tourism enterprises.

We have used the Community Innovation Survey's operational definition of innovation that was used in the fourth survey carried out in 2004 (CIS IV). CIS IV differentiates between four kinds of innovation: product innovation, process innovation, organisational innovation, and marketing innovation [13]. Product innovation is the introduction into the market of a new good or service or a significantly improved good or service with respect to its capabilities. Process innovation is the implementation of a new or significantly improved production process, distribution method or support activity for the enterprise's goods or services. An organisational innovation is the implementation of new or significant changes in a given enterprise's structure or management methods that are intended to improve the enterprise's use of knowledge, the quality of goods and services or the efficiency of work flows. A marketing innovation is the implementation of new or significantly improved designs or sales methods in order to increase the appeal of the enterprise's goods and services or to enter new markets.

With the exception of product innovation, several questions (variables) measured the different types of innovation. (See appendix A for a more comprehensive explanation.)

In the following statistical analysis, the variable Product innovation is dichotomous. During the years 2004-2007, either the respondent has introduced a new or significantly improved product or the respondent has not introduced a new or improved product. Process innovation, Organisational innovation and Marketing innovation can assume ratio scales that count the number of specific processes the enterprises implement in organisational and marketing innovations, respectively (see appendix A). We have used these ratio scales additionally by having constructed a fifth measurement of innovation, Total innovation activity. This variable is the sum of the four types of innovation (i.e., product, process, organisational, and marketing innovation). More precisely, we have added up the dichotomous variables of innovation. The new variable is metric, therefore.

We conducted multiple regression analyses when testing the hypothesis. The objective of multiple regression analysis is to predict the changes in the dependent variable in response to changes in the several independent variables. This objective is most often achieved through the statistical rule of least squares [49]. In other words, multiple regression analyses are used to examine the explanatory power of the independent variables on the variance in the independent variable.

The general multiple regression model is:

$$
\mathrm{Y}_{\mathrm{i}}=\beta_{0}+\beta_{1} \mathrm{X}_{1 i}+\beta_{2} \mathrm{X}_{2 i}+\ldots .+\beta_{\mathrm{k}} \mathrm{X}_{\mathrm{k} i}+\mathrm{u}_{i}, \mathrm{i}=1, \ldots, \mathrm{n}
$$

$\mathrm{Y}_{\mathrm{i}}$ is the dependent variable, and the $i^{\text {th }}$ observation of the dependent variable. The subscript $i$ covers observations from $i=1, \ldots, n . \beta_{0}$ is the regression constant (the intercept of population regression line). $\mathrm{X}_{1 \mathrm{i}}, \mathrm{X}_{2 \mathrm{i}}, \ldots, \mathrm{X}_{\mathrm{k} i}$ are the $i^{\text {th }}$ observations on each of the $k$ regressors, and $\mathrm{u}_{i}$ is the error term [50].

It is also possible to include beta coefficients in the statistics reported. The beta coefficient is the standardised regression coefficient that allows for a direct comparison between coefficients with respect to their relative explanatory power of the dependent variable. However, beta coefficients should only be used as a guide for the relative importance of the predictor variables [51].

We have conducted in total five regression analyses with product, process, organisational, and marketing innovations as well as total innovation activity as dependent variables.

The dependent variable of product innovation is dichotomous, and there is a popular belief that linear regression should not be used when the dependent variable is dichotomous. Hellevik does not, however, agree with this belief, and states that the statistical arguments against the use of linear regression with a binary dependent variable are not as decisive as it is often claimed. Even if the assumption of homoscedasticity is violated, this in practice has little effect on the outcome of significance tests. The results for linear and logistic significance probabilities turn out to be nearly identical, even with small samples and skewed distributions on the dependent variable. The problem of impossible predictions may be avoided by including interactions terms in the regression equation or by transforming continuous variables into dummy variables, or both. These options mean that we are not restricted to using logistic regression with a binary dependent variable. This is fortunate, claims Hellevik, since in many cases there are compelling substantive arguments for preferring the linear approach. As the dependent variable is binary $(0,1)$, the regression coefficient indicates the change of probability for value 1 on the dependent variable by one unit increase of the predictor, after multivariate control for relevant independent variables. The change of probability is measured by percentage points [52].

We have used one-tailed significance tests because the hypotheses are quite well underpinned by both theoretical considerations and previous research. We expected positive associations between the dependent and the independent variables. This expectation led to our sole focus on the null hypothesis, $\mathrm{H}_{0}$, of the form $\mathrm{H}_{1}$ : $\beta \mathrm{j}>0$, which implied the irrelevance of the alternatives to $\mathrm{H}_{0}$ of the form $\mathrm{H}_{1}$ : $\beta \mathrm{j}<0$ [53].

We employed the statistical software package STATA to conduct the statistical analysis.

\section{RESULTS}

\section{The Variables Used in the Analyses}

According to the hypotheses, the independent variables are cooperation, involvement of employees in the enterprise's development processes, the enterprise's action to increase employees' competence, market information system, public grants, and exporting orientation. In addition, the variables of size of enterprise and the enterprise's age were entered into the analysis as controlling variables. Descriptive statistics are reported in Table $\mathbf{1}$.

The variable of product innovation is dichotomous. The average score of 0.43 indicates that 43 per cent of the 
Table 1. Variables Included in the Analyses. Descriptive Statistics

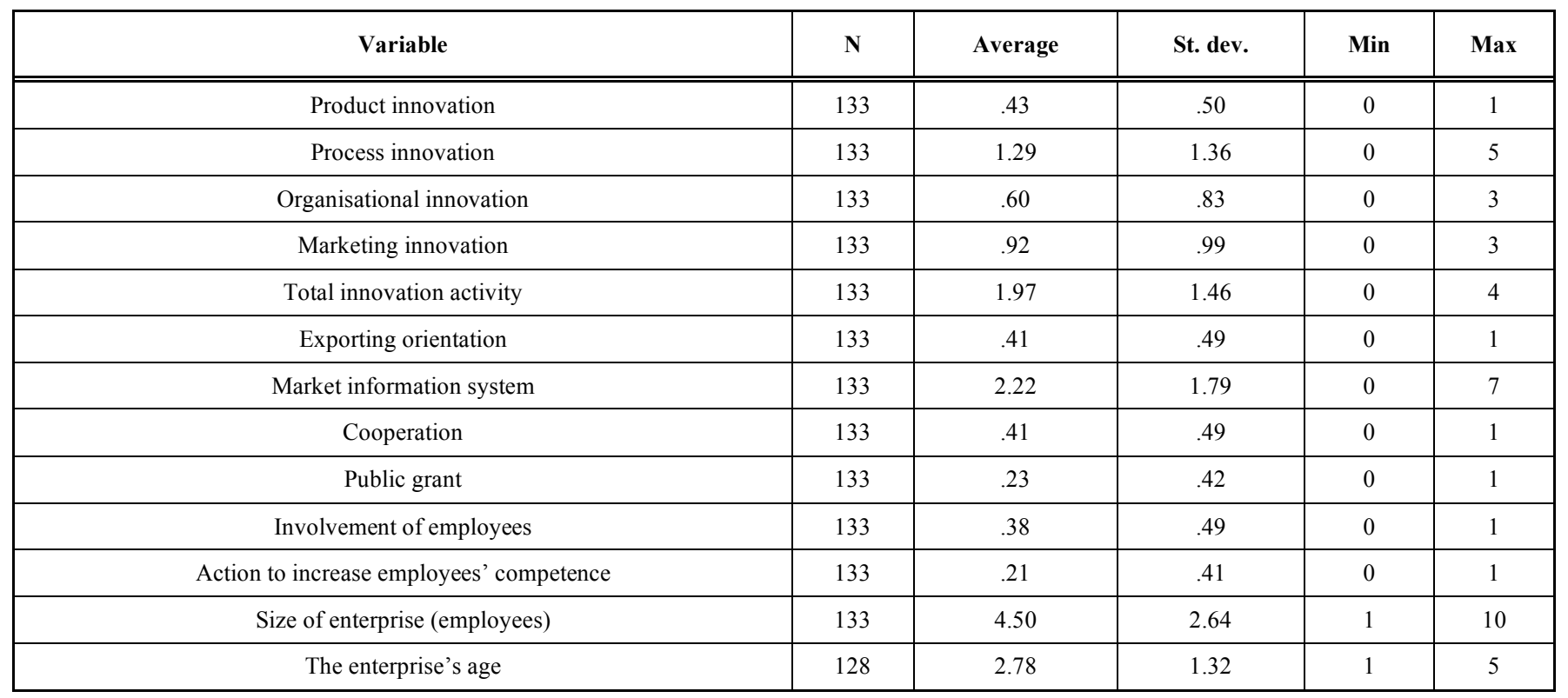

enterprises have implemented this major type of innovation during the period 2004-2007.

The variables of process, organisational, and marketing innovation are ratio scales that count the number of specific kinds of process, organisational, and marketing innovations, respectively, implemented by the enterprises. The variable of process innovation covers a maximum of four specific types of process innovations. The average score is 1.29, which indicates that the enterprises on the average have implemented 1.29 specific types of process innovations during the period 2004-2007. Similarly, the enterprises on average have implemented 0.60 specific types of organisational innovations, and 0.92 specific types of marketing innovations during the same period. The variable of total innovation activity is the sum of the four major types of innovation (i.e., product, process, organisational, and marketing innovations). More precisely, we have added up the dichotomous innovation variables. On the average the enterprises had implemented 1.97 major types of innovation during the period 2004-2007.

The variable Exporting orientation is dichotomous. Value 0 indicates that an enterprise does not export services, and value 1 indicates that the enterprise exports some of their services, but the proportion is not stated. The average score, 0.41 , indicates that 41 per cent of the enterprises export services.

The variable Cooperation is also dichotomous. The variable reflects the cooperation that is established to improve the participants' innovative capacity. Value 1 indicates that an enterprise is involved in cooperation to increase its innovation capacity. Value 0 indicates the opposite. The average score, 0.41 , indicates that 41 per cent of the enterprises participate in this kind of cooperation.

The variable Market information system counts how many steps the enterprise has undertaken to gather information about customers' evaluations of the enterprise's services, potential market segments' needs and preferences, market trends, competing enterprises, etc. On average, the enterprises have undertaken 2.2 steps. This variable touches upon acquisition of knowledge and learning processes relevant to innovation.

The variable Action to increase employees' competence is dichotomous, and indicates whether or not the enterprise has taken actions to increase employees' competence. The average score, 0.21 , shows that 21 per cent of the enterprises have undertaken such efforts.

The variable Involvement of employees (in the enterprise's developmental processes) is dichotomous. Value 1 states that the enterprise has involved employees in such processes, and value 0 states the opposite. The average score, 0.38 , shows that 38 per cent of the enterprises have involved employees in the enterprise's developmental processes.

The final predictor, Public grant, is dichotomous. Value 1 states that the enterprise has acquired public grants, and value 0 the opposite. The average score, 0.23 , indicates that 23 per cent of the enterprises have acquired some kind of public grant.

The controlling variable Size of enterprise shows that the enterprises on average have 4.5 employees, including both part- and full-time employees. The controlling variable The enterprise's age is ordinal. Value 1 indicates that the enterprise is less than 5 years old, value $2=5-10$ years of age, value $3=11-20$ years, value $4=21-40$ years, and value $5=$ more than 41 years of age. The average score is 2.8 , which indicates that the enterprises on average are close to the category 11-20 years of age.

\section{The Innovation Rates}

Before we present the regression analyses, it is worthwhile to have a brief look at the rates of innovation. Table 2 provides the innovation rates stated in the tourism innovation 
Table 2. Innovative Activities in Rural Tourism Enterprises and other Tourism Enterprises during the Period of 2004 - 2007, and the Innovative Activities in all Norwegian Industries Except the Tourism Industry and Agriculture During $2002-2004{ }^{i}$

\begin{tabular}{|c|c|c|c|c|}
\hline \multirow{2}{*}{ Major type of innovation } & \multicolumn{3}{|c|}{$\begin{array}{c}\text { The innovation survey including tourism enterprises in } \\
\text { Norway (2008) }\end{array}$} & \multirow{2}{*}{$\begin{array}{c}\text { Statistics Norway's } \\
\text { innovation survey (2004) }\end{array}$} \\
\hline & $\begin{array}{l}\text { Rural tourism } \\
\text { enterprises }\end{array}$ & $\begin{array}{l}\text { Other tourism } \\
\text { enterprises }\end{array}$ & Sign $^{\text {iv }}$ & \\
\hline $\begin{array}{c}\text { Proportion of enterprises that have implemented } \\
\text { product innovation }\end{array}$ & $43 \%(n=133)$ & $\begin{array}{c}50 \% \\
(\mathrm{n}=285)\end{array}$ & $\begin{array}{c}\mathrm{chi}=1.946 \\
\mathrm{p}=0.163\end{array}$ & $\begin{array}{c}21 \% \\
(\mathrm{n}=4655)\end{array}$ \\
\hline $\begin{array}{c}\text { Proportion of enterprises that have implemented } \\
\text { process innovation }\end{array}$ & $59 \%(n=133)$ & $\begin{array}{c}70 \% \\
(n=285)\end{array}$ & $\begin{array}{c}\mathrm{chi}=5.069 \\
\mathrm{p}=0.021\end{array}$ & $\begin{array}{c}16 \% \\
(n=4655)\end{array}$ \\
\hline $\begin{array}{c}\text { The average number of specific process innovations } \\
\text { in the enterprises }\end{array}$ & $1.29(\mathrm{n}=133)$ & $\begin{array}{c}1.75 \\
(\mathrm{n}=285)\end{array}$ & $\begin{array}{c}\mathrm{F}=8.82 \\
\text { Sig. }=0.03\end{array}$ & \\
\hline $\begin{array}{c}\text { Proportion of enterprises that have implemented } \\
\text { organisational innovation }\end{array}$ & $42 \%(n=133)$ & $\begin{array}{c}51 \% \\
(\mathrm{n}=285)\end{array}$ & $\begin{array}{c}\mathrm{chi}=2.795 \\
\mathrm{p}=0.095\end{array}$ & $\begin{array}{c}22 \% \\
(n=4655)\end{array}$ \\
\hline $\begin{array}{l}\text { The average number of specific organisational } \\
\text { innovations in the enterprises }\end{array}$ & $0.6(n=133)$ & $\begin{array}{c}0.8 \\
(\mathrm{n}=285)\end{array}$ & $\begin{array}{c}\mathrm{F}=4.33 \\
\text { Sig. }=0.038\end{array}$ & \\
\hline $\begin{array}{c}\text { Proportion of enterprises that have implemented } \\
\text { marketing innovations }\end{array}$ & $53 \%(n=133)$ & $\begin{array}{c}64 \% \\
(n=285)\end{array}$ & $\begin{array}{c}\mathrm{chi}=4.459 \\
\mathrm{p}=0.035\end{array}$ & $\begin{array}{c}20 \% \\
(\mathrm{n}=4655)\end{array}$ \\
\hline $\begin{array}{l}\text { The average number of specific marketing } \\
\text { innovations in the enterprises }\end{array}$ & $0.92(n=133)$ & $\begin{array}{c}1.14 \\
(\mathrm{n}=285)\end{array}$ & $\begin{array}{l}\mathrm{F}=3.86 \\
\mathrm{p}=0.050\end{array}$ & \\
\hline
\end{tabular}

${ }^{i}$ In the tourism innovation survey carried out in 2008, the tourism enterprises stated their innovative activities during the period of 2004 - 2007 (see the section on methodology). In 2004 Statistics Norway carried out an innovation survey that included enterprises from all Norwegian industries except the tourism industry and agriculture. In Statistics Norway's survey, the enterprises stated their innovative activities during the period of $2002-2004$. The figures have been given by Salte [30].

ii The term of rural tourism enterprises is defined in the section on methodology.

iii Other tourism enterprises are localised in (more) central geographical areas or have more than ten employees.

${ }^{\text {iv }}$ Chi-square test (when differences in percentages are tested) or One-Way ANOVA (when differences in the average scores are tested).

survey from 2008 (see the section on methodology). In addition, Table 2 includes the innovation rates reported in the Norwegian innovation survey, which Statistics Norway carried out in 2004. Statistics Norway's survey includes all Norwegian industries except tourism and agriculture.

We should note that a direct comparison between the Norwegian national innovation survey carried out in 2004 by Statistics Norway and the Norwegian tourism innovation survey (2008) may have various sources of error. The most obvious source of error is the difference in the registration periods. Statistics Norway's survey included innovative activities over three years $(2002-2004)$, while the tourism innovation survey from 2008 included innovative activities over four years $(2004-2007)$. It is necessary, then, for the innovative activities stated in the survey from 2004 to be increased by approximately 33 per cent (1/3) in order to compensate for the difference in registration periods. Another source of error relates to financial matters because the rate of interest was somewhat higher during $2002-2004$ than during $2004-2007$. The higher level of the rate of interest during 2002 - 2004 may have hampered the innovative activities of that period compared to the following years. Even if the comparison between the two surveys is burdened with some uncertainty, the inclusion of the rates from Statistics Norway's survey offers a rough frame of reference.

First of all, we may ascertain from Table 2 that the rates of innovation in the tourism industry are quite high even if rural tourism enterprises are not as innovative as the other tourism enterprises. However, Table 2 indicates that the rural tourism enterprises' rates of innovation are probably higher than the average rates for other Norwegian industries. It appears that there is no support for hypothesis 1, which states that the innovative activities in rural tourism activities are low and considerably lower than the average for other Norwegian industries Thus, hypothesis 1 should be rejected because the innovation rates in the rural tourism enterprises are rather high.

\section{Regression Analyses}

Table 3 presents the results from the five regression analyses.

All analyses were tested for heteroscedasticity with the Breusch-Pagan/Cook-Weisberg test for heteroscedasticity [54], and for multicollinearity with the Variance Inflation Score for multicollinearity [55]. No problems were reported except for problems with heteroscedasticity in analyses numbers II and III. The problems were solved by using heteroscedasticity-robust standard error and heteroscedasticity-robust $t$ statistic in these analyses [56].

Analysis I indicates that the predictors of exporting orientation, market information system, cooperation, and public grants tend to increase the enterprises' ability to implement product innovations. The predictors of exporting orientation, cooperation, and public grants are all dichotomous. The dependent variable is also dichotomous. The interpretation of the regression coefficients in the multiple regression analysis where the dependent variable is dichotomous is explained in the section of methodology. However, one should be careful of using the results in Analysis I as a basis for exact predictions because the dependent variable is binary and some of the predictors are not dichotomous. The 
Table 3. Five Analyses with the Four Major Types of Innovation and Total Innovation Activity as Dependent Variables. Multiple Regression Analyses, OLS. Regression Coefficients, t Statistics in Parentheses ()

\begin{tabular}{|c|c|c|c|c|c|}
\hline \multirow[b]{2}{*}{ Predictors: } & \multicolumn{5}{|c|}{ Dependent variable: } \\
\hline & $\begin{array}{c}\text { Analysis I: } \\
\text { Product } \\
\text { innovation }\end{array}$ & $\begin{array}{l}\text { Analysis II: } \\
\text { Process } \\
\text { innovation }\end{array}$ & $\begin{array}{c}\text { Analysis III: } \\
\text { Organisa-tional } \\
\text { innovation }\end{array}$ & $\begin{array}{l}\text { Analysis IV: } \\
\text { Marketing } \\
\text { innovation }\end{array}$ & $\begin{array}{c}\text { Analysis V: } \\
\text { Total innovation } \\
\text { activity }\end{array}$ \\
\hline Size of enterprise & $0.019(1.18)$ & $0.055(1.12)$ & $0.002(0.07)$ & $0.007(0.26)$ & $0.0572(1.39)$ \\
\hline The enterprise's age & $-0.030(-0.99)$ & $-0.040(-0.50)$ & $-0.039(-0.72)$ & $0.039(0.73)$ & $-0.0570(-0.73)$ \\
\hline Cooperation & $0.159 *(1.80)$ & $0.473 *(1.87)$ & $0.189(1.23)$ & $0.682 * * *(4.38)$ & $0.879 * * *(3.90)$ \\
\hline Public grants & $0.236 *(2.31)$ & $-0.004(-0.01)$ & $0.206(1.03)$ & $0.439 * *(2.44)$ & $0.569 *(2.19)$ \\
\hline Involvement of employees & $-0.017(-0.17)$ & $0.215(0.73)$ & $0.410 *(2.05)$ & $0.107(0.60)$ & $0.236(0.92)$ \\
\hline $\mathrm{N}$ & 128 & 128 & 128 & 128 & 128 \\
\hline
\end{tabular}

estimates from the binary variable regression can produce impossible predicted likelihoods, with values above 1 . However, we have also conducted a logistic regression analysis (equal to the model in Analysis I) that produced about the same results as the linear regression analysis. The logistic regression analysis indicates the same positive and significant relationships between the dependent variable and the predictors, as the linear regression analysis did (see Table 1 in Appendix B). Consequently, we may interpret the tendencies in Analysis I thus: enterprises with an exporting orientation are more likely to implement product innovations than those enterprises without an exporting orientation (coefficient $=0.174, \mathrm{p}<.05)$. Enterprises that participate in cooperation are more likely to implement product innovations than those that do not participate in cooperation (coefficient $=0.159, \mathrm{p}<.05$ ). Furthermore, enterprises that receive public grants are more likely to implement product innovation than those that do not acquire public grants (coefficient $=0.236, \mathrm{p}<.05$ ). And finally, the probability of product innovation increases as the enterprises carry out one or more actions to gather market information (coefficient $=$ $0.051, \mathrm{p}<.05)$.

Analysis II suggests that the predictors of market information system, cooperation, and actions to increase employees' competence tend to increase the enterprises' ability to implement specific process innovations.

The regression coefficient shows that the enterprises on average implement 0.13 specific process innovations as the enterprises carry out one more actions to get market information (coefficient $=0.134, \mathrm{p}<.05$ ). Enterprises that participate in cooperation on average implement about 0.5 more specific process innovations than enterprises that do not join in cooperative activities (coefficient $=0.473, \mathrm{p}<.05$ ). Finally, enterprises that take actions to increase their employees' competence on average implement about 0.7 more specific process innovations than enterprises that do not concentrate on employees' competence (coefficient $=$ $0.675, \mathrm{p}<.05)$.

The explained variance is somewhat higher than in Analysis I (adjusted $\mathrm{R}^{2}=0.25$ ).

Analysis III suggests that the predictors of market information system, involvement of employees, and actions to increase employees' competence tend to increase the enterprises' ability to implement specific organisational innovations.

The regression coefficient shows that the enterprises on average implement 0.08 specific organisational innovations as the enterprises carry out one more actions to acquire market information (coefficient $=0.078, \mathrm{p}<.05$ ). Enterprises that involve employees in the enterprises' developmental processes implement on average about 0.4 more specific organisational innovations than enterprises that do not involve employees (coefficient $=0.410, \mathrm{p}<.05)$. Finally, enterprises that take actions to increase employees' competence on average implement about 0.5 more specific organisational innovations than enterprises that do not concentrate on employees' competence (coefficient $=0.451$, $\mathrm{p}<.05)$.

The explained variance is somewhat better when compared with the former analyses (adjusted $\mathrm{R}^{2}=0.31$ ).

Analysis IV suggests that the predictors of market information system, cooperation, public grants, and actions to increase employees' competence tend to increase the enterprises' ability to implement specific marketing innovations.

The regression coefficient shows that the enterprises on average implement 0.09 specific marketing innovations as 
the enterprises carry out one more actions to gather market information (coefficient $=0.085, \mathrm{p}<.05)$. Enterprises that participate in cooperation implement on the average 0.7 more specific marketing innovations than those enterprises that do not practise cooperation (coefficient $=0.682, \mathrm{p}<.001$ ). Furthermore, enterprises that receive public grants implement on the average 0.4 more specific marketing innovations than enterprises that do not acquire public grants (coefficient $=0.439, \mathrm{p}<.01$ ). Finally, enterprises which take actions to increase employees' competence on average implement about 0.6 more specific marketing innovations than enterprises that do not concentrate on employees' competence $($ coefficient $=0.564, \mathrm{p}<.01)$.

The explained variance is rather high, and indicates that the model fits well to the data (adjusted $\mathrm{R}^{2}=0.37$ ).

In Analysis V, the dependent variable is total innovation activity, which includes all the major innovation types (product, process, organisational, and marketing innovations).

The analysis demonstrates that the predictors of market information system, cooperation, public grants, and actions to increase employees' competence tend to increase the enterprises' ability to implement innovations.

The regression coefficient shows that the enterprises on the average implement about 0.2 major types of innovation as the enterprises carry out one more actions to get market information (coefficient $=0.167, \mathrm{p}<.01$ ). Enterprises which participate in cooperation implement on the average 0.9 more major types of innovation compared with enterprises that do not join in cooperative efforts (coefficient $=0.879$, $\mathrm{p}<.001)$. Furthermore, enterprises which receive public grants implement on the average 0.6 more major types of innovation than enterprises that do not acquire them (coefficient $=0.569, \mathrm{p}<.05$ ). Finally, enterprises which take actions to increase employees' competence on the average implement about 0.7 more major types of innovation than enterprises that do not concentrate on employees' competence $($ coefficient $=0.637, \mathrm{p}<.01)$.

The explained variance (adjusted $\mathrm{R}^{2}=0.41$ ) is quite high, and indicates that the model fits the data well.

\section{DISCUSSION AND CONCLUSION}

We have deduced seven hypotheses on innovation in the rural tourism industry. We have already rejected hypothesis 1 that states that the innovative activity in rural tourism enterprises is low. The innovative activity is actually quite comprehensively (see Table 1), which is rather surprising. Tether's research has indicated that service enterprises reported low rates of product and process innovations because the respondents were overwhelmed by problems relating to the definitions of various innovations [21]. One difficulty relates to the distinction between the adaptation of services to customers' preferences, on the one hand, and service innovation, on the other. A related complication is that service innovation typically arises through continuous change or minor changes of service products or procedures rather than through discrete jumps. Obviously, the Norwegian rural tourism enterprises have not met this problem by stating low rates of innovations. It is possible that the Norwegian survey was plagued by the opposite problem of tourism enterprises having reporting excessively high rates of innovation. The enterprises may have dealt with any possible uncertainty regarding the definitions by reporting ordinary developmental processes, such as product development, as innovations. More research is needed in order to clarify these issues.

Hypothesis 2 suggests that enterprises participating in cooperation are more innovative than enterprises which do not join cooperative activities. In general, the hypothesis has been verified, with the exception of the association between cooperation and organisational innovations. Indeed, there are fairly strong statistical associations between cooperation and marketing innovations and total innovation activity, respectively. Obviously, appropriate cooperative or collaborative constellations tend to increase the enterprises' innovative ability. This finding gives grounds for a rather robust piece of advice: enterprises that need to strengthen their innovative capacity should endeavour to develop or improve networks, cooperation, and appropriate relations in general with other enterprises and actors of relevance. Yet, neither our findings nor previous research on the relationship between cooperation and innovation reveals exactly how cooperation strengthens the enterprises' innovative capacity. Cooperation may, for instance, lead to better financial capacity (e.g., joint investments) or to access to or exchange of knowledge, competence or ideas about new products and services or marketing, for instance. There is, however, a need for further research in order to gain more specific scientific knowledge about how small-scale enterprises actually benefit from cooperation and collaborative structures.

Hypothesis 3 states that enterprises which give priority to obtaining relevant information from external sources, for example, market information, are more innovative than enterprises that do not. This hypothesis has been verified, because the predictor of market information system demonstrates significant effects in all the analyses, even if the statistical associations are not very strong. We can refine market information to mean the kinds of valuable and relevant knowledge for the enterprises' innovative activities. Accordingly, this finding corresponds well with previous research about innovative processes that documents the importance of knowledge for increasing innovative capacity. We should also notice that hypotheses 3 and 4 concerns two aspects of the same phenomenon; knowledge and competence are key resources for innovative activities. This finding also provides the basis for another practical recommendation: enterprises that must strengthen their innovative capacity should give priority to acquiring relevant market information from external resources. This advice is compatible with the findings from previous research on the significance of market orientation [57].

Hypothesis 4 states that the enterprises which take actions to increase their employees' competence are more innovative than other enterprises. By and large, the hypothesis has been verified. The exception is the association between this predictor and product innovation. In fact, there are rather strong statistical associations between this predictor and the other types of innovations. This finding substantiates yet another recommendation: enterprises that want or need to strengthen their innovative capacity should 
endeavour to increase their employees' - and thereby the enterprises' - competence.

Hypothesis 5 states that enterprises that involve employees in the enterprises' developmental processes are more innovative than other enterprises. Our analyses suggest that involvement of employees tend to increase organisational innovations. There are, however, no significant associations between the involvement of employees and other types of innovations. The hypothesis has thus been rejected, with the exception of a single analysis.

Hypothesis 6 states that enterprises that qualify for public grants are more innovative than those that do not. The hypothesis has been partly verified because public grants tend to increase product innovations and marketing innovations along with total innovative activity.

Hypothesis 7 states that enterprises with an exporting orientation have more product innovations than other enterprises. The hypothesis has been verified even if the statistical association is not strong.

We can now draw some conclusions:

The survey indicates rather high rates of innovations among rural tourism enterprises.

Cooperation, market-information system, and actions to increase the enterprises' competence seem to be particularly important for increasing the enterprises' innovative capacity.

These findings give grounds for some recommendations: enterprises that want to or need to strengthen innovative capacity should endeavour to develop or improve business networks, cooperation, and relations in general with other actors. Secondly, enterprises should engage in actions that increase employees' competence in order to gain more innovative capacity. Thirdly, enterprises should give priority to acquiring information and knowledge, or at least relevant market information, from external resources.

The results also justify some reflections about the conceptual model in Fig. (1). More precisely, the antecedents mentioned in the model can be more specifically outlined. According to Sundbo, Orfila-Sintes, and Sørensen, the factors facilitating innovation can be related to different levels: the level of the firm, the network level, and the level of innovation system [58].

First, three predictors in Table $\mathbf{3}$ reflect some conditions for innovation that are primarily related to the level of the firm. One condition is the firms' decision to carry out actions to improve the employees' competence. The second antecedent is the firms' decision to involve the employees in the developmental processes. The third antecedent is the firms' decision to export services to foreign markets.

Secondly, some antecedents are primarily related to the firms' involvement in external relations. External relations may be interpreted as elements on the network level, according to Sundbo, Orfila-Sintes, and Sørensen [58]. One important aspect at this level is the firms' ability to participate in and utilise cooperation with relevant actors to improve their innovative ability. Another aspect relates to the firms' ability to implement a market-information system that brings about relevant information from external sources. Both aspects may be interpreted as qualities of networks and external relations, even if the individual firms have to decide if they want to connect to networks or to take part in external relations.

Finally, the firms' ability to qualify for public grants affects their innovative ability. This antecedent touches upon the role of governmental bodies as described in the triplehelix model and related theories about systems of innovation. The predictor of public grants, of course, reflects the firms' ability to qualify for public support. On the other hand, the acquirement of public grants presupposes that the government has implemented means and rules that give the firms the opportunity to qualify for grants. Consequently, according to Sundbo, Orfila-Sintes, and Sørensen [58], the predictor of public grants may be interpreted as an aspect on the system level.

The aim of the paper was to provide a picture of innovativeness and the differences in innovativeness in rural tourism industry. The analyses have brought about such a picture and have provided an understanding of the differences in innovative activities. This understanding is rooted in the review of literature, and is principally verified by the analyses. The results have also given grounds for some specific outlines of the conditions of and antecedents to innovativeness.

It is necessary, however, to carry out further research due to the fact that research on innovations has rarely focused on small-scale rural tourism enterprises. First of all, it is important to explore small-scale enterprises' interpretations of the term innovation and the major types of innovations. We should do well to ask if the rather high rates of innovation reported by the enterprises could be due to the enterprises' misconception of innovation activities. In other words, have the enterprises confused innovation with the ordinary work of, say, product development or marketing? It is probably necessary to conduct a qualitative study of small tourism enterprises to answer this question adequately.

Secondly, the effect of cooperation on innovative capacity should be studied in depth in order to explore the mechanisms at work. Neither our findings nor previous research about the relationship between cooperation and innovation reveal exactly how cooperation strengthens the enterprises' innovative capacity.

Thirdly, the processes of knowledge transfer require more thorough study. Our analyses demonstrate that the acquisition and transfer of information and knowledge affect the enterprises' innovative ability. The analyses also indicate that the enterprises' actions to increase their employees' competence influence the enterprises' innovative capacity. We have, however, only revealed some statistical associations. It should, then, be of interest to study the knowledge processes more in detail in order to identify the problems and barriers as well as the adequate and successful moves to increase the enterprises' basis of knowledge that is relevant to innovative ability.

Finally, we do not know how different categories of rural enterprises representing somewhat different industries or services perform with respect to innovations. We do not know, for instance, if enterprises offering nature-based tourism services, culture-based services, agritourism services 
or staged experiences have different rates of innovation or if they innovate in different ways.

\section{ACKNOWLEDGEMENTS}

The author would like to acknowledge Lillehammer University College for conducting the survey and the Centre for Rural Research for partly funding the survey. This paper is also a part of two research projects, Innovation in smallscale rural tourism: How to organise and co-operate for improvement and expansion? at Centre for rural studies, and
Innovation in the Tourism Industry at Lillehammer University College. The research projects are mainly funded by The Research Council of Norway.

The author would like to thank Lillehammer University College and the Centre for Rural Research for funding the work with this paper and for funding the collection of data used in the analysis. The author would also like to thank certain colleagues at Lillehammer University College, Professor Håvard Teigen and Assistant professor Hans Holmengen, for their contribution to the questionnaire and their efforts related to the implementation of the survey.

\section{Appendix A}

\section{DEFINITIONS AND MEASUREMENTS OF INNOVATIONS, AND THE WORDING OF QUESTIONS REGARDING INNOVATION TO THE RESPONDENTS}

All definitions and measurements have principally been developed by the Community Innovation Survey IV (CIS IV) (see ref. 8 in References), with minor modifications. Additionally, the questionnaire used in the Norwegian study of innovation in tourism enterprises differs somewhat regarding the process and marketing innovations (see below).

\section{Product Innovation}

The respondents were introduced to the following definition of product innovation: "A product (good or service) innovation is the market introduction of a new good or service or a significantly improved good or service with respect to its capabilities. The innovation must be new to the enterprise, but it does not need to be new to the market. Purely aesthetic changes or innovations completely developed by other actors should not be included".

The respondents were then asked, "Has the enterprise implemented product innovations during the period 2004-2007?" The respondents could answer "yes" or "no" to this question. Accordingly, this variable is dichotomous.

Additionally, the enterprises were asked if the product innovations were new only to the enterprise or also to the enterprise's market. This formulation made it possible to construct a variable with three values: a) no new or significantly improved goods or services have been implemented; b) new or significantly improved goods or services which are new to the enterprise have been implemented; and c) new or significantly improved goods or services which are new to the enterprise's market have been implemented.

We have employed the dichotomous variable in our analysis.

\section{Process Innovation}

The respondents were given the following definition of process innovation: "A process innovation is the implementation of a new or significantly improved production technology or production process, or distribution method. The innovation must be new to the enterprise, but it does not need to be new to the enterprise's sector or market. Exclude purely organisational innovations".

Then the respondents were asked: "Has the enterprise implemented any of the specific process innovations mentioned below during the period 2004-2007?

- New or significantly improved methods of manufacturing or producing goods or services.

- New or significantly improved logistics, delivery or distribution methods for your inputs, goods or services.

- New or significantly improved supporting activities for your processes, such as maintenance systems or operations for purchasing, accounting or computing.

- New or significantly improved degree of service quality.

- New or significantly improved standards concerning physical production factors."

The respondents could answer "yes" or "no" to every question in the list above.

The two last questions listed above are not included in CIS IV, but were included in the Norwegian survey on tourism enterprises. 
It is possible to construct a dichotomous variable for process innovation $(0=$ the respondent has not implemented any of the specific process innovations, $1=$ the respondent has implemented at least one of the specific process innovations). It is also possible to construct a ratio scale with the values $0=$ no specific types of process innovations are implemented, $1=$ one of the specific types of process innovations is implemented, $2=$ two of the specific types of process innovations are implemented, $3=$ three of the specific types of process innovations are implemented, etc. The maximum value is $5=$ all five specific types of process innovations are implemented. We have used the ratio scale in our analysis.

\section{Organisational Innovation}

The respondents were told the following definition of organisational innovation: "An organisational innovation is the implementation of new or significant changes in enterprise structure or management methods that are intended to improve the enterprise's use of knowledge, or to improve the quality of your goods and services, or to improve the efficiency of work flows".

The respondents were then asked: "Has the enterprise implemented any of the specific organisational innovations mentioned below during the period 2004-2007?

- $\quad$ New or significantly improved knowledge-management systems to use or exchange information, knowledge and skills better within the enterprise.

- A major change to the organisation of work within the enterprise, such as changes in the managerial structure or integration of different departments or activities.

- New or significant changes in your relations with other enterprises or public institutions, such as through alliances, partnerships, outsourcing or sub-contracting".

The respondents could answer "yes" or "no" to every question in the list above.

It is possible to construct a dichotomous variable for organisational innovation $(0=$ the respondent has not implemented any of the specific organisational innovations, $1=$ the respondent has implemented at least one of the specific organisational innovations). It is also possible to construct a ratio scale with the values $0=$ no specific types of organisational innovations are implemented, $1=$ one of the specific types of organisational innovations is implemented, 2 = two of the specific types of organisational innovations are implemented, $3=$ all three specific types of organisational innovations are implemented. We have used the ratio scale in our analysis.

\section{Marketing Innovation}

The respondents were given the following definition of organisational innovation: "A marketing innovation is the implementation of new or significantly improved marketing or sales methods to increase the appeal of the enterprise's goods and services or to enter new markets".

Then the respondents were asked: "Has the enterprise implemented any of the specific marketing innovations mentioned below during the period 2004-2007?

- $\quad$ Significant changes to the design or packaging of a good or service (exclude routine/ seasonal changes).

- New or significantly changed sales or distribution methods, such as internet sales, franchising, direct sales or distribution licenses.

- Orientation towards and sales to new market segments".

The respondents could answer "yes" or "no" to every question in the list above.

It is possible, then, to construct a dichotomous variable $(0=$ the respondent has not implemented any of the specific marketing innovations, $1=$ the respondent has implemented at least one of the specific o marketing innovations). It is also possible to construct a ratio scale with the values $0=$ no specific types of marketing innovations are implemented, $1=$ one of the specific types of marketing innovations is implemented, 2 = two of the specific types of marketing innovations are implemented, 3 = all three specific types of marketing innovations are implemented. We have used the ratio scale in our analysis.

\section{Total Innovation Activity}

The variable total innovation activity is a sum of the four major types of innovation (product, process, organisational, and marketing innovations). More precisely, we have added up the dichotomous innovation variables accounted for above. The new variable is thus metric, where value $0=$ none of the major types of innovation are implemented, $1=$ one of the major types of innovation is implemented, etc. The maximum value is $4=$ all four major types of innovation are implemented. 


\section{Appendix B}

Table 1. Logistic Regression Results with Product Innovation as Dependent Binary Variable. Logistic Regression Coefficients (logit) and $t$ Statistics in Parentheses

\begin{tabular}{|c|c|}
\hline Predictors: & $0.108(1.24)$ \\
\hline Size of enterprise & $-0.188(-1.12)$ \\
\hline The enterprise's age & $0.952 *(2.08)$ \\
\hline Exporting orientation & $0.289 *(2.06)$ \\
\hline Market-information system & $0.817 *(1.86)$ \\
\hline Cooperation & $1.292 * *(2.36)$ \\
\hline Public grants & $-0.0931(-0.18)$ \\
\hline Involvement of employees & $0.532(1.00)$ \\
\hline Actions to increase employees' competence & 128 \\
\hline N & 0.22 \\
\hline Pseudo ${ }^{2}$ & \\
\hline
\end{tabular}

\section{REFERENCES}

[1] Hall CM, Müller DK, Saarinen J. Nordic Tourism: Issues and Cases. Bristol: Channel View 2009.

[2] Hall D, Mitchell M, Roberts L. Tourism and the countryside: Dynamic relationships. In: Hall D, Mitchell M, Roberts L, Eds. New Directions in Rural Tourism. Aldershot: Ashgate 2003.

[3] Sharpley R. Tourism and leisure in the countryside. Kings Ripton: Elm 2005; pp. 1-1.

[4] Saarinen J. Contradictions of Rural Tourism Initiatives in Rural Development Contexts: Finnish Rural Tourism Strategy Case Study. Curr Issues Tourism 2007; 10(1): 96-105.

[5] Nærings- og Handelsdepartementet. Verdifulle opplevelser. Nasjonal strategi for reiselivsnæringen. Regjeringens reiselivsstrategi, Nærings-og handelsdepartementet. Oslo: Næringsog handelsdepartementet, 2007.

[6] Hjalager AM. Repairing innovation defectiveness in tourism. Tourism Manage 2002; 23: 465-74.

[7] Fagerberg J. Innovation: A Guide to the Literature. In: Fagerberg J, Mowery DC, Nelson RR, Eds. The Oxford handbook of innovation. Oxford: Oxford University Press 2005; pp.1-26.

[8] Verspagen B. Innovation and Economic Growth. In: Fagerberg J, Mowery DC, Nelson RR, Eds. The Oxford handbook of innovation. Oxford: Oxford University Press 2005; pp. 487-513.

[9] Ioannides D, Petersen T. Tourism 'non-entrepreneurship' in peripheral destinations: a case study of small and medium tourism enterprises on Bornholm, Denmark. Tourism Geogr 2003; 5(4): 408-5.

[10] Mattsson J, Sundbo J, Fussing-Jensen C. Innovation Systems in Tourism: The Roles of Attractors and Scene-Takers. Ind Innov 2005; 12(3): 357-381.

[11] Peters M, Pikkemaat B. Innovation in Tourism. J Qual Assur Hosp Tourism 2005; 6(3/4): 1-6.

[12] Fussing-Jensen C, Mattson J, Sundbo J. Innovationstendenser i dansk turisme. Forskningsrapport 01:1. Roskilde: Center for Servicestudier, Roskilde Universitetscenter 2001.

[13] Organisation for Economic Co-operation and Development, Statistical Office of the European Community. The Measurement of Scientific and Technological Activities. Oslo Manual: Guidelines for Collecting and Interpreting Innovation Data, $3^{\text {rd }}$ ed. Paris: OECD Publishing 2005.

[14] Sharpley R, Sharpley J. Rural Tourism. An Introduction. London: International Thomson Business Press 1997; p. 5.

[15] Lane B. What is rural tourism? J Sustainable Tourism 1994; 2(1\&2): 7-15.

[16] Lane B. What is Rural Tourism? In: Bramwell B, Lane B, Eds. Rural Tourism and Sustainable Rural Development. Clevedon: Channel View Publications 1994.
[17] Saxena G, Clark G, Oliver T, Ilbery B. Conceptualizing Integrated Rural Tourism. Tourism Geogr 2007; 9(4): 347-70.

[18] Leiper N. The framework of tourism. Ann Tourism Res 1979; 6(4): 390-407.

[19] Schumpeter J. The Theory of Economic Development. London: Transaction Books 1934.

[20] Coombs R, Miles I. Innovation, Measurement and Services: The New Problematic. In: Metcalfe JS, Miles I, Eds. Innovation Systems in the Service Sectors. Measurement and Case Study Analysis. Boston, Dordrecht and London: Kluwer 2000; 85-104.

[21] Tether BS. Do Services Innovate (Differently)? Insights from the European Innobarometer Survey. Ind Innov 2005; 12(2): 153-184.

[22] Boden M, Miles I. Services and the Knowledge-Based Economy. London: Continuum 2000.

[23] Gadrey J, Gallouj F. The Provider-Customer Interface in Business and Professional Services. Serv Indust J 1998; 18(2): 1-15.

[24] Gallouj F, Weinstein O. Innovation in services. Res Policy 1997; 26(4/5): 537-56.

[25] Sundbo J, Gallouj F. Innovation as a loosely coupled systems in services. In: Metcalfe JS, Miles I, Eds. Innovation Systems in the Service Sectors. Measurement and Case Study Analysis. Boston, Dordrecht and London: Kluwer 2000.

[26] Sundbo J, Gallouj F. Innovation in services in seven European countries. Roskilde: Center for servicestudier, Roskilde Universitetscenter 1999.

[27] Gallouj F. Innovation in the Service Economy. The New Wealth of Nations. Cheltenham: Edward Elgar 2002.

[28] Mohnen P, Mairesse J, Dagenais M. Innovativity: A comparison across seven European countries. Econ Innov New Technol 2006; 15(4/5): 391-413.

[29] Robson S, Haigh G. First findings from the UK Innovation Survey 2007. Econ Labour Market Rev 2008; 2(4): 47-53.

[30] Salte ØV. Innovasjon i norsk næringsliv (Innovation in Norwegian Industries). Oslo: Statistisk Sentralbyrå (Statistics Norway); 2007. Rapporter 2007/42.

[31] Pechlaner H, Fischer E, Hammann EM. Leadership and innovation processes - development of products and services based on core competencies. J Qual Assu Hosp Tourism 2005; 6(3/4): 31-57.

[32] Sørensen F. The Geographies of social networks and innovation in tourism. Tourism Geog 2007; 9(1): 22-48

[33] Orfila-Sintes F, Crespi-Cladera R, Martinez-Ros E. Innovation activity in the hotel industry: Evidence from Balearic Islands. Tourism Manag 2005; 26(6): 851-65.

[34] Ottenbacher M, Shaw V, Lockwood A. An investigation of the factors affecting innovation performance in chain and independent hotels. J Qual Assur Hosp Tourism 2005; 6(3/4): 113-28.

[35] Bolkesjø T, Haukeland PI, Vareide K. Innovativ fjellturisme. Innovasjonsaktivitet og innovasjonsbehov på 7 destinasjoner Buskerud, Telemark og Aust Agder. Bø: Telemarksforskning-Bø; 2003. Arbeidsrapport nr. 16 
[36] Rønningen M, Kvam G-T, Stræte EP. Samarbeid om innovasjon mellom småbedrifter i norsk bygdeturisme - en forstudie. Trondheim: Norsk senter for bygdeforskning/Centre for Rural Research; 2007. Notat nr 5/07.

[37] Asheim BT, Gertler MS. The Geography of Innovation: Regional Innovation Systems. In: Fagerberg J, Mowery DC, Nelson RR, Eds. The Oxford Handbook of Innovation, Oxford: Oxford University Press 2005; pp. 291-317.

[38] Edquist C. Systems of Innovation: Perspectives and Challenges. In: Fagerberg J, Mowery DC, Nelson RR, Eds. The Oxford Handbook of Innovation. Oxford: Oxford University Press 2005; pp. 181-208.

[39] Isaksen A, Karlsen A, Sæther B, Eds. Innovasjoner i norske næringer: et geografisk perspektiv. Bergen: Fagbokforlaget 2008.

[40] Lazzeretti L, Petrillo CS. Tourism local systems and networking. Amsterdam: Elsevier 2006. Malerba F. Sectorial Systems of Innovation: Concepts, Issues and Analyses of Six Major Sectors in Europe. Cambridge, UK: Cambridge University Press 2004.

[41] Lundvall B-Å. National Systems of Innovation: Towards a Theory of Innovation and Interactive Learning. London: Pinter Publishers 1992.

[42] Karlsen J. Læring, kunnskap og innovasjon fra et organisatorisk ståsted. In: Isaksen A, Karlsen A, Sæther B, Eds. Innovasjoner i norske næringer: et geografisk perspektiv. Bergen: Fagbokforlaget 2008; 81-97.

[43] Etzkowitz H, Leydesdorff L. The Dynamics of innovation: From national systems and 'Mode 2' to triple helix of university-industrygovernment relations. Res Policy 2000; 29(2): 109-24.

[44] Isaksen A, Asheim B. Den regionale dimensjonen ved innovasjoner. In: Isaksen $\mathrm{A}$, Karlsen $\mathrm{A}$, Sæther $\mathrm{B}$, Eds. Innovasjoner i norske næringer: et geografisk perspektiv. Bergen: Fagbokforlaget 2008; pp. 19-40.

[45] Lien G, Teigen H. Finansiering og innovasjon. In: Teigen H, Mehmetoglu M, Haraldsen T, Eds. Reiseliv, opplevelser og Kultur. Bergen: Fagbokforlaget 2009; 40-56.

[46] Statitics Norway. Standard Industrial Classification (SIC2002) [Online]. 2009 Sep 19, [cited Oct 7th 2009]. Available from:
http://www3.ssb.no/stabas/ItemsFrames.asp?ID=5556001\&Langua ge $=$ en

[47] Wägar K, Björk P, Ravald A, West B. Exploring Marketing in Micro Firms. Helsingfors: Swedish School of Economics and Business Administration 2007. Working Papers.

[48] Statitics Norway. Centrality 2008 [Online]. 2009 May 29, [cited Oct 7th 2009]. Available from: http://www3.ssb.no/stabas/Items Frames.asp $?$ ID $=5285601 \&$ Language $=$ en $\&$ VersionLevel $=$ classversi on\&MenuChoice $=$ Language

[49] Hair JF, Anderson RE, Tatham RL, Black WC. Multivariate data analysis. Upper Saddle River, New Jersey: Prentice Hall 2006; pp. 85-86.

[50] Stock JH, Watson MW. Introduction to econometrics. Boston: Pearson Addison Wesley 2007; p. 196

[51] Hair JF, Anderson RE, Tatham RL, Black WC. Multivariate data analysis. Upper Saddle River, New Jersey: Prentice Hall 2006; pp. 125-126.

[52] Hellevik O. Linear versus logistic regression when the dependent variable is a dichotomy. Qual Quant 2009; 43(1): 59-74.

[53] Wooldridge JM. Introductory Econometrics: A Modern Approach. Cincinatti, Ohio: South-Western College Publishing Thompson Learning 1999; pp.118-123.

[54] Cook RD, Weisberg S. Diagnostics for Heterokedasticity in Regression. Biometrica 1983; 38: 159-178.

[55] Chatterjee S, Hadi AS, Price B. Regression Analysis by Example. New York: John Wiley \& Sons 2000.

[56] Wooldridge JM. Introductory Econometrics: A Modern Approach. Cincinatti, Ohio: South-Western College Publishing Thompson Learning 1999; pp. 250-251.

[57] Jaworski BJ, Kohli AK. Market orientation: Antecedents and consequences. J Mark 1993; 57(3): 53.

[58] Sundbo J, Orfila-Sintes F, Sørensen F. The innovative behaviour of tourism firms - Comparative studies of Denmark and Spain. Res Policy 2007; 36: 88-106.

This is an open access article licensed under the terms of the Creative Commons Attribution Non-Commercial License (http: //creativecommons.org/licenses/by$\mathrm{nc} / 3.0 /$ ), which permits unrestricted, non-commercial use, distribution and reproduction in any medium, provided the work is properly cited. 